\title{
Secondary dengue infection in immunocompetent murine model leads to heart tissue damage
}

\author{
F. C. JÁCOME, A. L. TEIXEIRA DE ALMEIDA, D. D. COUTINHO DE SOUZA, A. DA COSTA RASINHAS, \\ G. C. CALDAS, M. A. NUNES DA SILVA, O. M. BARTH, D. F. BARRETO-VIEIRA
}

\author{
Laboratory of Morphology and Viral Morphogenesis, Oswaldo Cruz Institute, Fiocruz; Av. Brasil, 4365, \\ Manguinhos 21040-360, Brazil
}

Received October 10, 2018; accepted November 23, 2018

\begin{abstract}
Summary. - Dengue, considered the most important arthropod-borne viral disease affecting humans, is transmitted by the bite of mosquitoes of the genus Aedes and caused by one of the four distinct serotypes of dengue virus (DENV-1, -2, -3 and -4). Infection with one of the four serotypes provides lifelong homotypic immunity. However, immunity against the heterologous serotypes is transient. As a consequence, secondary infection may lead to severer manifestations due to cross-reactivity of antibodies and T-cells. Over 500,000 people are hospitalized every year and around 2,5 million, living in endemic areas, are at risk of infection. Given the background, the development of vaccines and anti-DENV drugs is of the utmost importance, as is the characterization of an animal model for testing them. The purpose of this study was to investigate ultrastructural alterations caused by DENV secondary infection in BALB/c mice heart. To achieve our goal, six BALB/c mice were infected with DENV-1 and, 4 months later, reinfected with DENV-2. Uninfected mice were used as negative controls. Heart samples were collected and processed for ultrastructural and histopathological analysis. Our results showed edema, endothelium activation characterized by the presence of transport vesicles, free platelets in interstitium, mitochondria presenting rarefied matrix and degenerated cristae, and disorganization of muscle fibers. These results point not only to BALB/c mice susceptibility to DENV infection, but also to the fact that, although it is not an often reported occurrence, dengue can lead to heart damage.
\end{abstract}

Keywords: dengue; experimental model; reinfection; $\mathrm{BALB} / \mathrm{c}$ mice

\section{Introduction}

Dengue (DEN), considered the most important human arbovirosis by the World Health Organization (WHO, 2016), is the leading cause of disease and death in tropics and subtropics, and represents a serious economic burden (WHO, 2016; Shepard et al., 2016). According to the Centers for Disease Control and Prevention (CDC, 2012), one third of the world's population lives in areas at risk for infec-

E-mail: fernandacunhajacome@gmail.com; phone: +55-021-26521869.

Abbreviations: $\mathrm{CDC}=$ Centers for Disease Control and Prevention; $\mathrm{DEN}=$ dengue; $\mathrm{DENV}=\mathrm{DEN}$ virus; $\mathrm{ECs}=$ endothelial cells; VLPs $=$ virus-like particles; $\mathrm{WHO}=$ World Health Organization tion. DEN is caused by one of the four distinct serotypes of dengue virus (DENV-1, $-2,-3$ and -4 ), and is transmitted by mosquitoes of the genus Aedes (Gubler, 2002). DENV are enveloped viruses, presenting icosahedral symmetry. Their genome is a positive-sense, single-stranded RNA, constituted of approximately 11,000 nitrogen bases, which encodes three structural (E, prM and C) and seven nonstructural (NS) proteins, only seen within infected cells (NS1, NS2A, NS2B, NS3, NS4A, NS4B and NS5) (Rice et al., 1985; Lindenbach and Rice, 2003). Infection with one of the four serotypes provides lifelong homotypic immunity. However, immunity against the heterologous serotypes is transient (Sabin, 1952). As a consequence, secondary infection may lead to severer manifestations of DEN due to cross-reactivity of non-neutralizing antibodies and/or proliferation of lowaffinity T-cells (Mathew and Rothman, 2008; Duangchinda 
et al., 2010; Remmy, 2014). Currently, there is no available treatment for DEN and the only way to prevent infection is avoiding the bite of Aedes mosquitoes in endemic areas (CDC, 2012). Therefore, characterization of animal models is of great relevance for better understanding DEN pathogenesis, as well as testing of vaccines and anti-viral drugs (Guzman et al., 2010). Dengue presents a wide range of cardiac manifestations. However, the outcome is frequently benign. It is not known if involvement of heart is a direct effect of viral infection of cardiac cells or caused by cellular immune responses and cytokine mediators released by different target tissues. Rhythm disturbance, raised levels of creatine kinase-MB and troponin I, acute myocardial infarction, acute pericarditis and third-degree atrioventricular block are among alterations associated with the disease (Warke et al., 2003; Arora and Patil, 2016; Ku and Yu, 2016; Virk et al., 2016). Studies carried out by Barreto et al. reported that immunocompetent BALB/c mice, when infected with nonneuroadapted DENV, present viremia as well as clinical signs such as tremor, diarrhea and increased body temperature. In addition, tissue alterations, similar to the ones seen in human cases of DEN, were observed in organs where viral genome was detected (Barreto et al., 2004, 2007, 2009, 2015; Barth et al., 2006; Jácome et al., 2015). Moreover, analysis of heart samples of mice infected with DENV-2 showed platelets, edema and mononuclear inflammatory cells in capillaries and in tissue interstice and signs of endothelium activation (Jácome et al., 2015). This paper reports histopathological and ultrastructural alterations found in heart samples of BALB/c mice infected with DENV-1 and reinfected with DENV-2 or -3 .

\section{Materials and Methods}

Ethical statement. All procedures performed during this study were approved by the Animal Ethic Committee (protocol LW50/11) and the Human Research Ethic Committee (protocol 247/05) of Fundação Oswaldo Cruz (Fiocruz).

Virus. DENV-1 (BR/RJ70145/2008), DENV-2 (BR/RJ66985/ 2000) and DENV-3 (BR/RJ289/2008) strains, kindly provided by Flavivirus Laboratory (Oswaldo Cruz Institute, Fiocruz) were isolated from serum samples of patients. Serotypes were confirmed by indirect immunofluorescence, using DENV-type-specific monoclonal antibodies (DENV-1: 15F3, DENV-2: 3H5 and DENV-3: 8A1), and qualitative real-time polymerase chain reaction (Lanciotti $e t$ al., 1992). Virus stock was prepared by inoculating $100 \mu \mathrm{l}$ of each strain into cell culture bottles containing mosquito Aedes albopictus cell line (C6/36) at a concentration of $5 \times 10^{5}$ cells $/ \mathrm{ml}$. Titers of the 3 strains (DENV-1: 107.5 TCID $_{50} / \mathrm{ml}$ DENV-2: $106.66 \mathrm{TCID}_{50} / \mathrm{ml}$ and DENV-3: $108.23 \mathrm{TCID}_{50} / \mathrm{ml}$ ) were calculated by the Reed \& Muench method (1938). The viruses did not undergo any passages through mice brain for neuroadaptation.
Mice. Two-month-old, male BALB/c mice, weighting about $25 \mathrm{~g}$, provided by ICTB (Fiocruz animal breeding center), were kept under controlled temperature, photoperiod, nutrition and hydration conditions during the experiment.

Experimental design. For histopathological studies, ten mice at two months of age were first infected by the intravenous (iv) route with DENV-1. Four months later, five mice were reinfected, also by the iv route, with DENV-2 and five, with DENV-3. Five uninfected mice were used as negative control. Seventy-two hours after secondary infection, the mice were anesthetized with pentobarbital sodium and euthanized for harvesting. Samples were fixed by immersion in Millonig's fixative. During the period between first infection and euthanasia, the animals were observed for identification/detection of clinical signs, such as temperature, tremors, petechiae caused by infection. For ultrastructural studies, six mice at two months of age were first infected with DENV-1 by the iv route. Reinfection was carried out four months after primary infection. Three mice were inoculated with DENV-2 and three, with DENV-3. Four noninfected mice were used as negative control. Seventy-two hours after the secondary infection, mice were anesthetized with pentobarbital sodium, fixed by perfusion with $4 \%$ paraformaldehyde in $0.2 \mathrm{M}$ sodium phosphate buffer and euthanized. Harvested samples were fixed by immersion in $2 \%$ glutaraldehyde in $0.2 \mathrm{M}$ sodium cacodylate buffer. Inocula volume was $100 \mu \mathrm{l}$ and viral concentration was 20,000 $\mathrm{TCID}_{50} / 0.1 \mathrm{ml}$ for DENV-1, 2,000 TCID $50.1 \mathrm{ml}$ for DENV-2 and 125,000 TCID 50 /0.1 ml for DENV-3.

Histopathology. Heart samples, previously fixed in Millonig's fixative, were dehydrated in increasing concentrations of ethanol and embedded in paraffin. Sections ( $5 \mu \mathrm{m}$ thick) were stained with hematoxylin and eosin and analyzed using a Zeiss Axiophot light field microscope.

Transmission electron microscopy. Heart samples were processed as described by Barreto-Vieira (2010). Briefly, samples were fixed by immersion in $2 \%$ glutaraldehyde diluted in sodium cacodylate buffer $(0.2 \mathrm{M}, \mathrm{pH} 7.2)$, cut into smaller fragments $\left(\sim 1 \mathrm{~mm}^{3}\right)$, post-fixed in $1 \%$ osmium tetroxide and dehydrated in increasing concentrations of acetone. Subsequently, samples were embedded in Epoxy resin (Electron Microscopy Sciences, USA). For light microscopy, semithin sections $(0.5 \mu \mathrm{m})$ were stained with methylene blue and azure II and analyzed using a Zeiss PrimoStar light microscope. Ultrathin sections were stained with uranyl acetate and lead citrate and analyzed using a Jeol JEM 1011 transmission electron microscopy.

\section{Results}

In order to mimic secondary infection, $\mathrm{BALB} / \mathrm{c}$ mice were infected with DENV-1 and reinfected, four months later, with either DENV-2 or -3. No mice died in the course of this experiment. They were all euthanized $72 \mathrm{~h}$ post-reinfection. Clinical signs, such as petechiae, tremors or diarrhea, as well as neurological signs, such as paralysis, were not observed, 


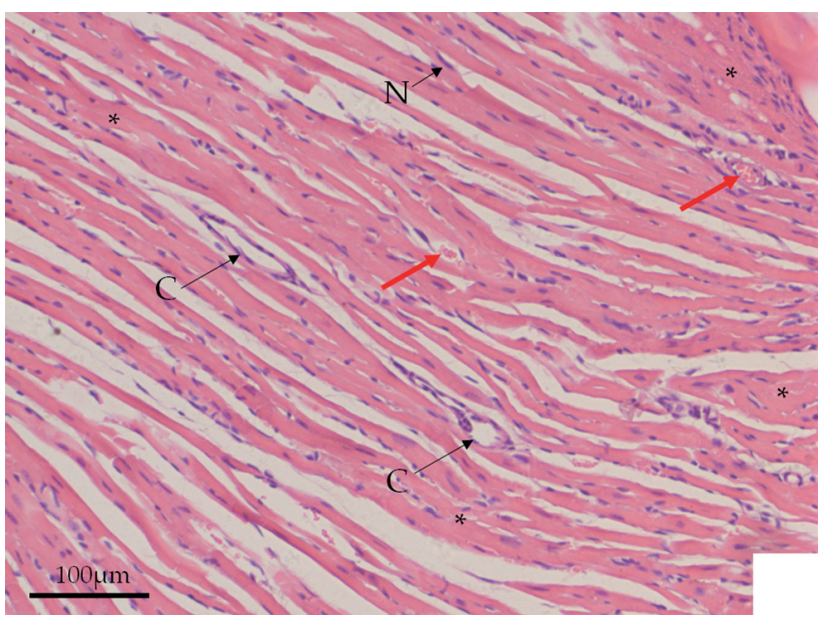

Fig. 1

Heart of uninfected BALB/c mice

Note organized fibers $(*)$, erythrocytes (red arrow) within integral capillaries $(\mathrm{C})$, nucleus $(\mathrm{N})$. however, on the tenth day after primary infection, all animals presented bristly fur.

The micrographs presented are representative of alterations seen in heart samples of BALB/c mice infected with DENV-1 and reinfected with DENV-2 or -3. Samples from control mice did not show alterations observed in infected samples (Fig. 1). Tissue alterations observed in animals reinfected with either DENV-2 or DENV-3 were similar. Our histopathological analyses showed focal alteration, mainly, vascular congestion (Fig. 2a,b,c), mononuclear cells (Fig. 2c) and erythrocytes (Fig. 2a-d) free in the interstice. Ultrastructural studies also revealed focal alterations: fluid accumulation was seen in capillaries, mononuclear cells were found free in the interstice (Fig. 3a) and cardiomyocyte mitochondria showed crista degeneration (Fig. 3c). Observed endothelial cells (ECs) seemed integral, presenting unaltered junctions (Fig. 3a-b), although some of them were swollen due to the presence of numerous vesicles within the cytoplasm (Fig. 4c). Additionally, intense membrane vesicle
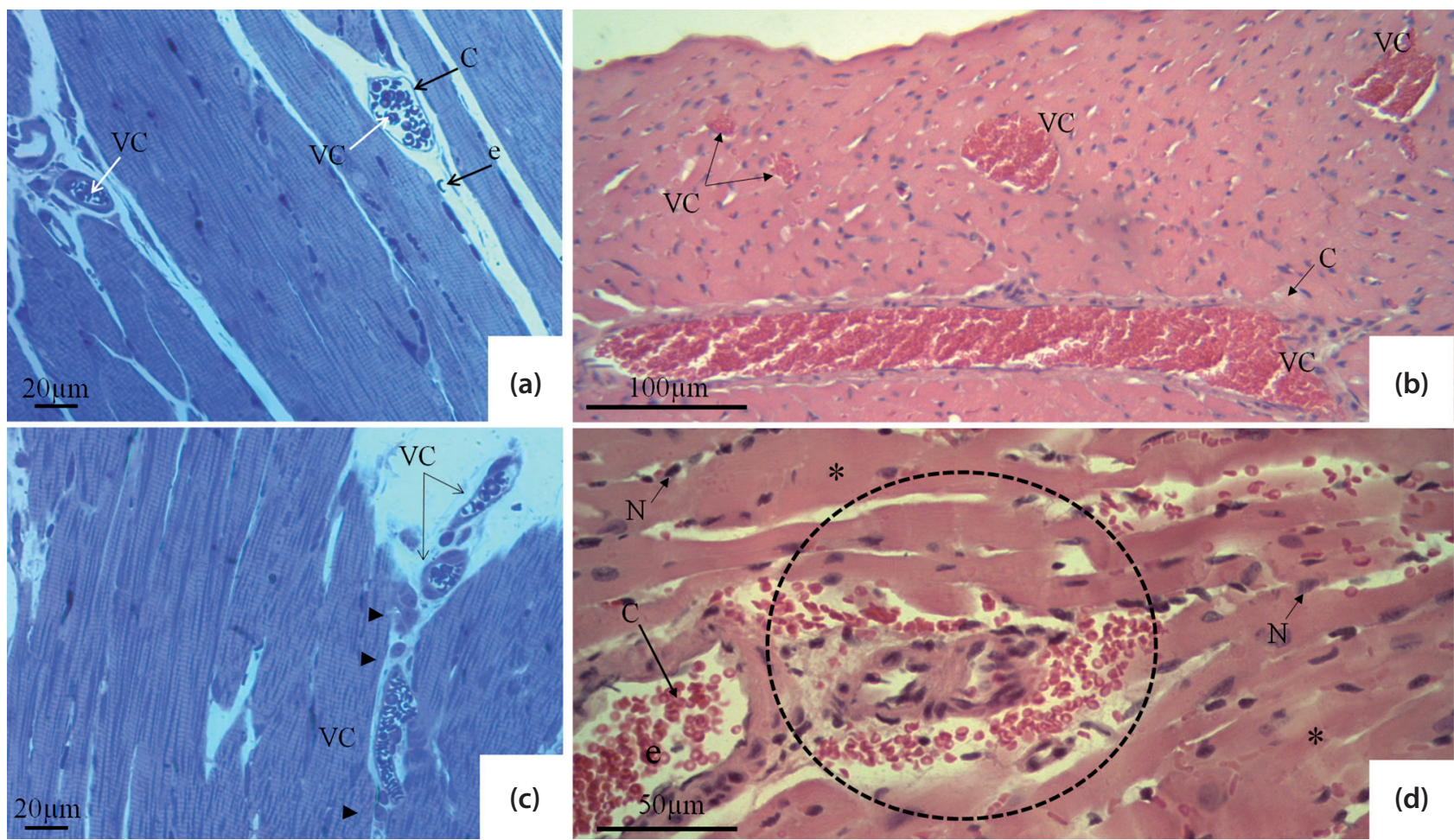

Fig. 2

Heart of BALB/c mice infected with DENV-1 and reinfected with DENV-2 or DENV-3 shows focal histopathological alterations (a, b and c) Vascular congestion (VC). (a and d) Erythrocytes free in the interstice (circled area). (c) Mononuclear cells (arrowhead) in the interstice. Capillary (C). [Reinfection. 2a, b, d: DENV-2; 2c: DENV-3]. 


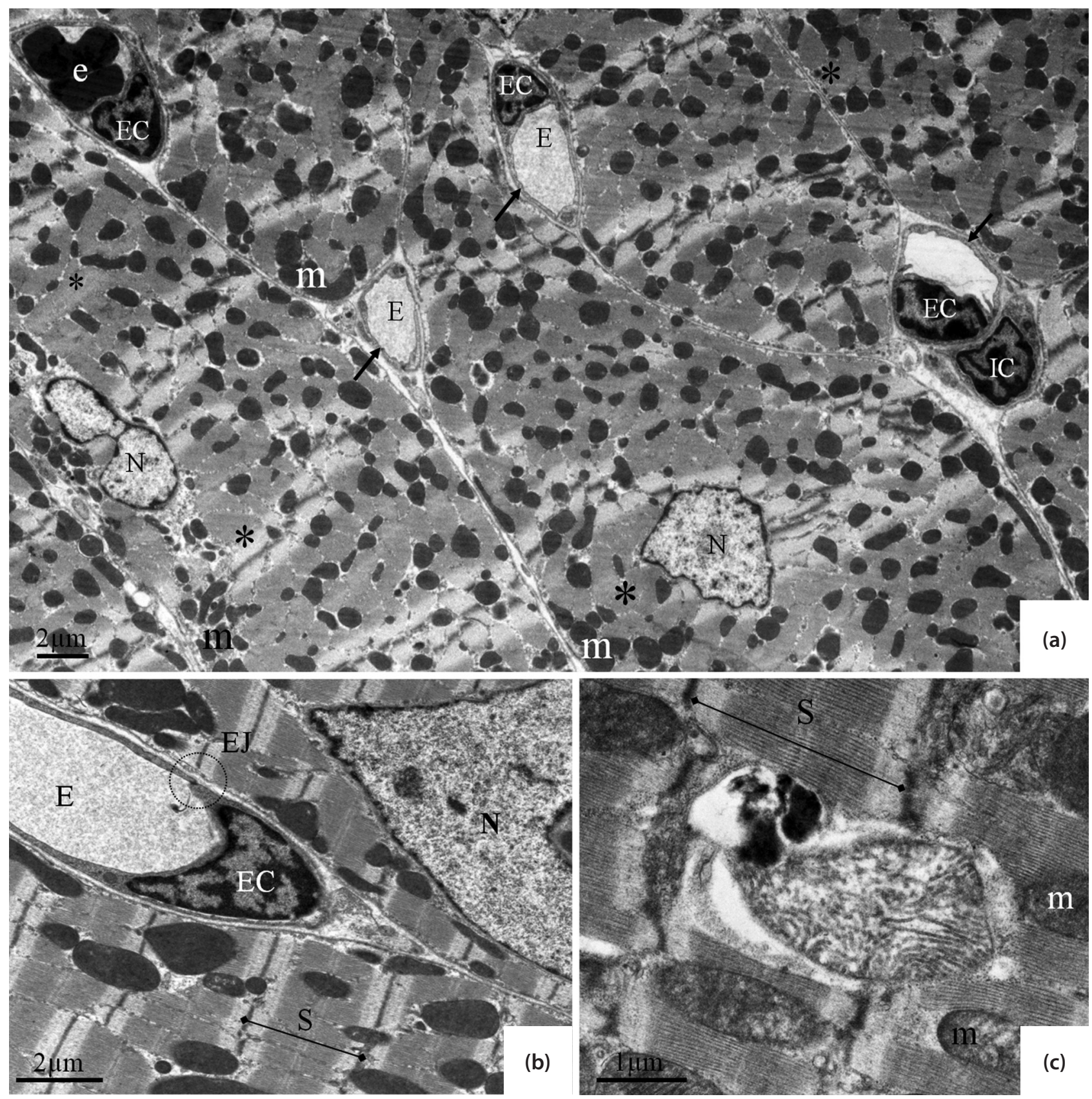

Fig. 3

Heart of BALB/c mice infected with DENV-1 and reinfected with DENV-2 shows focal ultrastructural alterations

(a and b) Organized fibers $\left({ }^{*}\right.$ ), capillary with unaltered endothelium (arrow), mononuclear cells (IC) free in the interstice. (b) Capillary showing intact endothelial junctions (EJ/circled area) and presenting fluid accumulation (edema) (E). (c) Mitochondrion (m) showing degeneration of its cristae (red arrows). Endothelial cell (EC), nucleus (N), sarcomere (S).

trafficking between ECs and cardiomyocytes (Fig. 4a-b) as well as degranulated platelets adhering to capillary walls and cardiomyocytes (Fig. 5a-b) could be observed, and viruslike particles (VLPs) were seen in the interstice between cardiomyocytes (Fig. 5c-d). The aforementioned alterations are commonly seen in cases of heart involvement during the course of DENV infecton. 

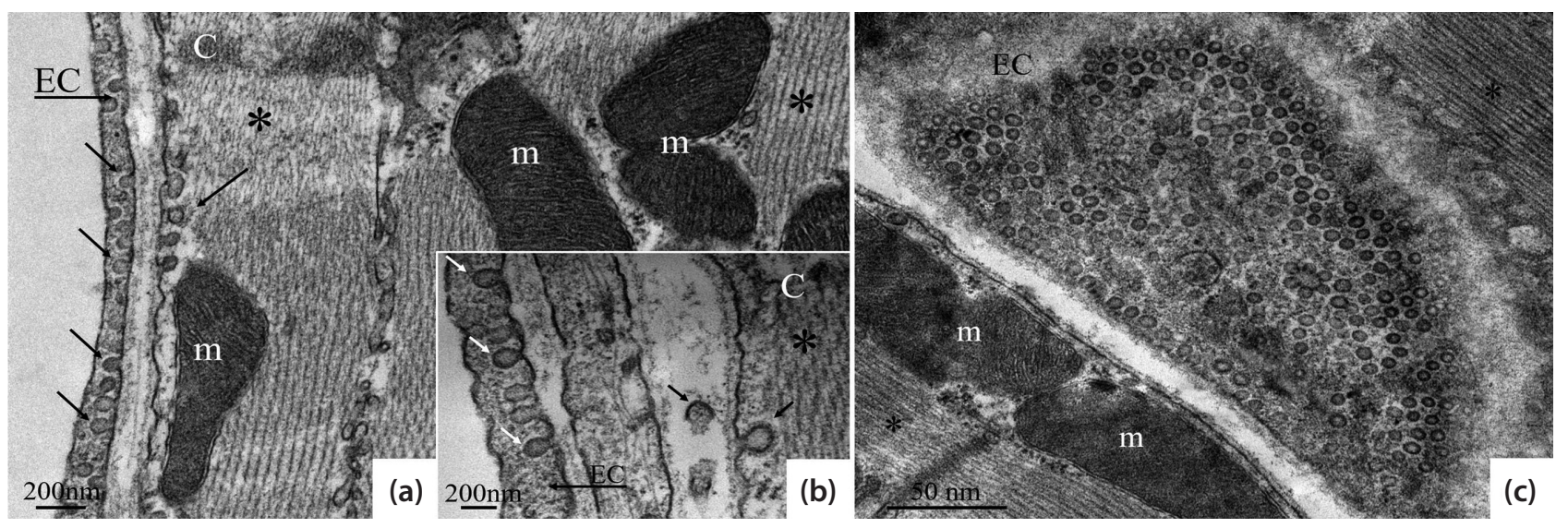

Fig. 4

Endothelial cells from heart of BALB/c mice infected with DENV-1 and reinfected with DENV-2 show signs of activation and swelling (a and $\mathbf{b}$ ) Intense membrane vesicle trafficking (arrows) between endothelial cells (EC) and cardiomyocytes (C). Mitochondria (m), fibers $\left({ }^{*}\right)$.
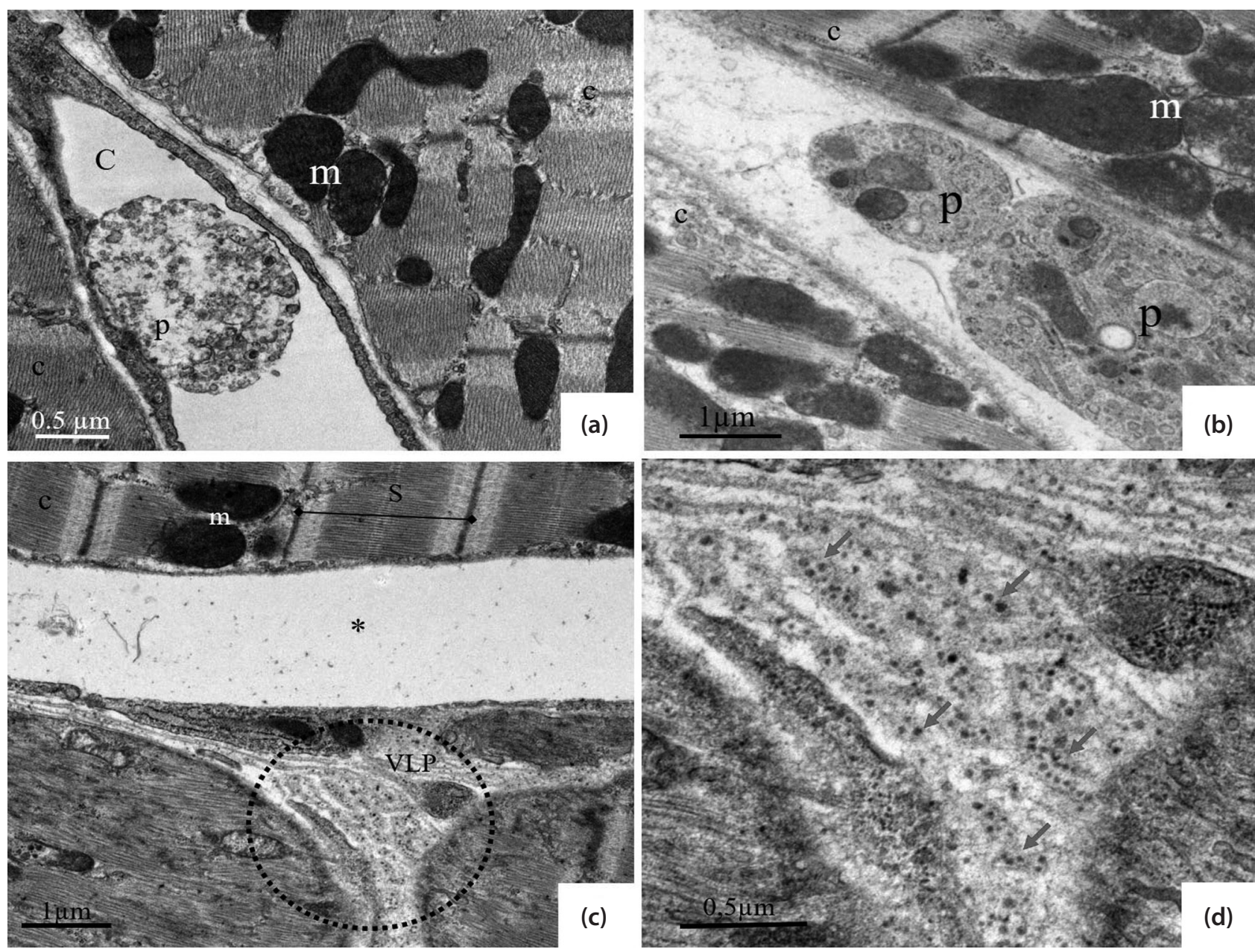

Fig. 5

Platelet adhesion and virus-like particles (VLPs) in heart samples from BALB/c mice infected with DENV-1 and reinfected with DENV-2 (a) Degranulated platelet (p) adhered to capillary (C) wall. (b) Platelet (p) adhered to cardiomyocytes. (c and d) (magnification of 5c area) VPL (red arrows) located in space among cardiomyocytes. Mitochondria $(\mathrm{m})$, sarcomere $(\mathrm{S})$, endomysium $\left(^{*}\right)$. 


\section{Discussion}

DEN presents a wide range of clinical manifestations with unpredictable outcome (Shepard et al., 2016) and, although the most frequently affected organ is the liver (Póvoa et al., 2014), DENV has been detected in other organs as well (Jessie et al., 2004; Lima et al., 2011). Whilst cardiac manifestations during DEN are among the least common ones, when present, they are often associated with severe forms of DEN. The most commonly seen cardiac impairment is myocarditis (Satarasinghe et al., 2007; Lee et al., 2009; Salgado et al., 2010; Weerakoon et al., 2011; Arora and Patil, 2016), which may be caused by indirect effect of cellular immune responses or cytokine mediators released from other DENV target tissues (Warke et al., 2003). However, studies carried out by Salgado et al. (2010) suggest that cardiac muscle dysfunction associated with DEN is the direct result of DENV infection of myocytes. Patients with primary and secondary DENV infection may develop severe cardiac dysfunction such as hypotension and arrhythmia (Kularatne et al., 2007; Sheetal et al., 2016). Cardiac rhythm disorders observed during course of infection are atrioventricular blocks, atrial fibrillation, sinus node dysfunction and ectopic ventricular beats (Chuah, 1987; Khongphatthallayothin et al., 2000; Veloso et al., 2003; Promphan et al., 2004). In order to assess the suitability of BALB/c mice as a model for studying cardiac involvement caused by DEN secondary infection, we were interested in seeing whether the morphological changes present in heart of infected mice could be associated to cardiac disorders seen in DEN patients. In our samples, mononuclear cells were seen infiltrated in the interstice, such findings are in accordance with DEN myocarditis reports (Shah, 2007; Lee et al., 2010; Marques et al., 2013; Póvoa et al., 2014). VLPs were observed in our samples, and, although it is not clear whether myocarditis is the direct effect of DENV infection of myocytes or indirectly caused by immune response mediated by cytokines, DENV-like particles were seen within cardiomyocytes of BALB/c mice infected with DENV-2 (Jácome et al., 2015). Thus, previous studies have confirmed the presence of DENV in human cardiac cells by detecting either the viral genome or the viral antigen (Jessie et al., 2004; De Araújo et al., 2009; Lima et al., 2011; Póvoa et al., 2014). Our results also show mitochondrial alterations characterized by degeneration of mitochondrial cristae. Ultrastructural analyses of fatal cases carried out by Póvoa (2014) also evidenced mitochondrial alterations as well as pycnotic nucleus, which suggest apoptotic process of cardiac fibers. Moreover, necrosis of myocardial fibers was observed in heart samples of DEN patients (GuadalajaraBoo et al., 2014). DENV has the ability to infect human ECs as demonstrated by previous studies (Jessie et al., 2004; Póvoa et al., 2014). In addition, it has been reported that a significant increase in number of infected hepatic ECs in a murine model for antibody dependent enhancement coincides with the onset of severe disease (Zellweger et al., 2010). Severe dengue disease is associated with extensive involvement of endothelium (Basu and Chaturvedi, 2008), however, morphological alterations are seldom reported (Chanthick et al., 2016). Our results show erythrocytes and inflammatory cells free in the interstice, which suggests endothelial permeability and corroborates findings of Yu and colleagues (1989), who analysed samples of skin eruptions of DEN patients. We did not see any evidence of plasma leakage, a common feature of more severe cases of DENV infection (WHO, 2009), however, we observed a number of capillaries presenting fluid accumulation. Our samples presented no severely damaged ECs, and the endothelial junctions we observed were intact. Swelling of few ECs was noted. These conditions were also observed in samples of capillaries in skin biopsies (Sahaphong et al., 1980). Sahaphong's results showed gap formations in vascular wall as well. Intense vesicle trafficking between ECs and cardiomyocytes was often observed and it has been pointed out that transcellular hyperpermeability may play a role in the pathogenesis of plasma leakage in severe forms of DEN (Myers and Wegner, 2017). Prominent increase in pinocytic vesicles in cytoplasm of endothelial cells was seen by Sahaphong and colleagues (1980). Thus, swelling of ECs seen in our samples resulted from the presence of numerous vesicles within cytoplasm, which may occur due to increase of caveolae-mediated albumin transcytosis in this cell type during DENV infection (Chanthick et al., 2016).

Thrombocytopenia is a hallmark for both mild and more severe forms of DEN (Hottz et al., 2011). This condition may be caused by infection of bone marrow hematopoietic cell populations, which reduces their proliferative capacity (Nakao et al., 1989; Basu and Chaturvedi, 2008), or destruction of platelets from peripheral blood due to lysis by the complement system and involvement of antiplatelet antibodies, or formation of platelet-EC and platelets-leucocyte aggregates (Azeredo et al., 2015). Our samples showed what could be the beginning of platelets-EC aggregation. Platelet showed signs of destruction, evidenced by cytoplasmic loss. Moreover, observed platelets presented degranulated cytoplasm, which, according to Ghosh (2008), is a sign of activation and supports statements of platelets activation during DENV infection (Hottz et al., 2014; Jeewandara et al., 2015).

\section{Conclusions}

Our results show that secondary infection of immunocompetent $\mathrm{BALB} / \mathrm{c}$ mice with DEN results in heart tissue alterations similar to the ones observed in human cases of the disease and that although it is not a common hallmark of 
DENV infection, cardiac involvement should be taken into consideration during DEN patient management.

Acknowledgments. We would like to acknowledge the support of the Oswaldo Cruz Institute (Fiocruz, Rio de Janeiro), the Rudolph Barth Electron Microscopy Platform (IOC, Fiocruz, Rio de Janeiro), the Pathology Laboratory (IOC, Fiocruz, Rio de Janeiro), the Coordenação de Aperfeiçoamento de Pessoal de Nível Superior (CAPES) and the Brazilian Council for Research and Development (CNPq).

\section{References}

Arora M, Patil RS (2016): Cardiac Manifestation in Dengue Fever. J. Assoc. Physicians India July 64, 40-44.

Azeredo EL, Monteiro RQ, De Oliveira Pinto LM (2015): Thrombocytopenia in dengue: Interrelationship between virus and the imbalance between coagulation and fibrinolysis and inflammatory mediators. Mediators Inflamm. 3, 138-142. https://doi.org/10.1155/2015/313842

Barreto DF, Schatzmayr HG, Takiya CM, Jácome FC, Silva MEV, Faria NRC, Nogueira RMR, Barth OM (2009): Histopathological and ultrastructural studies of lung tissue of mice reinfected with dengue virus serotype 1 or 2 . Virus Rev. Res. 14, 21-32. https://doi.org/10.17525/vrr.v14i2.28

Barreto DF, Takiya CM, Paes MV, Farias-Filho J, Pinhão AT, Alves AM, Costa SM, Barth OM (2004): Histopathological aspects of Dengue-2 virus infected mice tissues and complementary virus isolation. J. Submicrosc. Cytol. Pathol. 36, 121-30.

Barreto DF, Takiya CM, Schatzmayr HG, Nogueira RM, FariasFilho J C, Barth OM (2007): Histopathological and ultrastructural aspects of mice lungs experimentally infected with denguevirus serotype 2 . Mem. Inst. Oswaldo Cruz 102, 175-82. https://doi.org/10.1590/S007402762007000200009

Barreto DF, Barth MO, Schatzmayr HG (2010): Modelo animal experimental para o estudo da patogênese dos vírus dengue sorotipos 1 e 2. Editora Interciência: Rio de Janeiro, pp. 62-63. ISBN: 978-85-7193-235-7.

Barreto-Vieira DF, Takiya MC, Jácome FC, Rasinhas AC, Barth OM (2015): Secondary infection with dengue viroses in a murine model: morphological analysis. Indian J. Appl. Res. 5, 44-51.

Barth OM, Barreto DF, Paes MV, Takiya CM, Pinhão AT, Schatzmayr HG (2006): Morphological studies in a model for dengue-2 virus infection in mice. Mem. Inst. Oswaldo Cruz 101, 905-915. https://doi.org/10.1590/S0074$\underline{02762006000800014}$

Basu A, Chaturvedi UC (2008): Vascular endothelium: the battlefield of dengue viroses. FEMS Immunol. Med. Microbiol. 53, 287-299. https://doi.org/10.1111/j.1574695X.2008.00420.x
Centers for disease control and prevention (CDC). Available online: https://www.cdc.gov/dengue/prevention/index.html (Accessed on 10/05/2018).

Chanthick C, Kanlaya R, Kiatbumrung R, Pattanakitsakul S, Thongboonkerd V (2016): Caveolae-mediated albumin transcytosis is enhanced in dengue-infected human endothelial cells: A model of vascular leakage in dengue hemorrhagic fever. Sci. Rep. Aug 22; 6, 31855. https://doi. org/10.1038/srep31855

Chuah SK (1987): Transient ventricular arrhythmia as a cardiac manifestation in dengue haemorrhagic fever - a case report. Singapore Med. J. 28, 569-572.

de Araújo JM, de Filippis AM, Schatzmayr HG, de Araújo ES, Britto C, Cardoso MA, Camacho LA, Nogueira RM (2009): Quantification of dengue virus type 3 RNA in fatal and non-fatal cases in Brazil, 2002. Trans. R. Soc. Trop. Med. Hyg. 103, 952-954. https://doi.org/10.1016/j. trstmh.2009.01.025

Duangchinda T, Dejnirattisai W, Vasanawathana S, LimpitikulW, Tangthawornchaikul N, Malasit P, Mongkolsapaya J, Screaton G (2010): Immunodominant T-cell responses to dengue virus NS3 are associated with DHF. PNAS 107, 16922-16927. https://doi.org/10.1073/pnas.1010867107

Ghosh K, Gangodkar S, Jain P, Shetty S, Ramjee S, Poddar P, Basu A (2008): Imaging the interaction between dengue 2 virus and human blood platelets using atomic force and electron microscopy. J. Electron. Microsc. 57, 113-118. https://doi.org/10.1093/jmicro/dfn007

Guadalajara-Boo JF, Ruiz-Esparza ME, Frausto AA, Abraham MVS, Gaspar-Hernández J (2014): Histologic and Angiographic Imaging of Acute Shock Dengue Myocarditis. Rev. Esp. Cardiol. 67, 226-227. https://doi.org/10.1016/j. rec.2013.09.009

Gubler DJ (2002): Epidemic dengue/denguehemorrhagic fever as a public health, social, and economic problem in the 21st century. Trends Microbiol. 10, 100-103. https://doi. org/10.1016/S0966-842X(01)02288-0

Guzman MG, Halstead SB, Artsob H, Buchy P, Farrar J, Gubler DJ, Hunsperger E, Kroeger A, Margolis HS, Martínez E, Nathan MB, Pelegrino JL, Simmons C, Yoksan S, Peeling RW (2010): Dengue: a continuing global threat. Nat. Rev. Microbiol. 8, 7-16. https://doi.org/10.1038/nrmicro2460

Hottz E, Tolley ND, Zimmerman AG, Weyrich AS, Bozza FA (2011): Platelets in dengue infection. Drug Discov. Today Dis. Mech. 8, e33-e38. https://doi.org/10.1016/j. ddmec.2011.09.001

Hottz ED, Medeiros-de-Moraes IM, Vieira-de-Abreu A, de Assis EF, Vals-de-Souza R, Castro-Faria-Neto HC, Weyrich AS, Zimmerman GA, Bozza FA, Bozza PT (2014): Platelet activation and apoptosis modulate monocyte inflammatory responses in dengue. J. Immunol. 193, 1864-1872. https://doi.org/10.4049/jimmunol.1400091

Jácome FC, dos Santos FB, Rasinhas AC, da Silva MAN, Nunes PCG, Barth OM, Barreto DF (2015): Heart compromise and detection of dengue virus-like particles in cardiac tissue of experimentally infected murine model. Int. J. Res. Stud. Biosci. 3, 101-109. 
Jeewandara C, Gomes L, Wickramasinghe N, Gutowska-Owsiak D, Waithe D, Shyamali NLA, Ogg GS, Malavige GN (2015): Platelet activating factor contributes to vascular leak in acute dengue infection. PLoS Negl. Trop. Dis. 9, e0003459. https://doi.org/10.1371/journal.pntd.0003459

Jessie K, Fong MY, Devi S, Lam SK, Wong KT (2004): Localization of dengue virus in naturally infected human tissues, by immunohistochemistry and in situ hybridization. J. Infect. Dis. 89, 1411-1418. https://doi.org/10.1086/383043

Khongphatthallayothin A, Chotivitayatarakorn P, Somchit S, Mitprasart A, Sakolsattayadorn S, Thisyakorn C (2000): Morbitz type I second degree AV block during recovery from dengue hemorrhagic fever. Southeast Asian J. Med. Public Health 4, 642-645.

Ku YH, Yu WL (2016): Fatal Dengue Myocarditis despite the Use of Extracorporeal Membrane Oxygenation. Case Rep. Infect. Dis. 2016, 5627217. https://doi.org/10.1155/2016/5627217

Kularatne SAM, Pathirage MMK, Kumarasiri PVR, Gunasena S, Mahindawanse SI (2007): Cardiac complications of a dengue fever outbreak in Sri Lanka, 2005. Trans. R. Soc. Trop. Med. Hyg. 101, 804-808. https://doi.org/10.1016/j. trstmh.2007.02.021

Lanciotti RS, Calisher CH, Gubler DJ, Chang GJ, Vorndam AV (1992): Rapid detection and typing of dengue viruses from clinical samples by using reverse transcriptase-polymerase chain reaction. J. Clin. Microbiol. 30, 545-551.

Lee CH, Teo C, Low AF (2009): Fulminant dengue myocarditis masquerading as acute myocardial infarction. Int. J. Cardiol. 136, 69-71. https://doi.org/10.1016/j.ijcard.2008.05.023

Lee IK, Lee WH, Liu JW, Yang KD (2010): Acute myocarditis in dengue hemorrhagic fever: a case report and review of cardiac complications in dengue-affected patients. Int. J. Infect. Dis. 14, 919-922. https://doi.org/10.1016/j. ijid.2010.06.011

Lima, M da R, Nogueira RM, Schatzmayr HG, de Filippis AM, Limonta D, dos Santos FB (2011): A new approach to dengue fatal cases diagnosis ns1 antigen capture in tissues. PLoS Negl. Trop. Dis. 5, e1147. https://doi.org/10.1371/ journal.pntd.0001147

Lindenbach AD, Rice CM (2003): Molecular biology of Flaviviruses. Adv. Virus Res. 59, 23-61. https://doi.org/10.1016/S0065$\underline{3527(03) 59002-9}$

Marques N, Gan VC, Leo YS (2013): Dengue myocarditis in Singapore: two case reports. Infection 41, 709-714. https:// doi.org/10.1007/s15010-012-0392-9

Mathew A, Rothman AL (2008): Understanding the contribution of cellular immunity to dengue disease pathogenesis. Immunol. Rev. 225, 300-313. https://doi.org/10.1111/j.1600065X.2008.00678.X

Myers GJ, Wegner J (2017): Endothelial glycocalyx and cardiopulmonary bypass. J. Extra-Corpor. Technol. Sep (3), 174-181.

Nakao S, Lai CJ, Young NS (1989): Dengue virus, a flavivirus, propagates in human bone marrow progenitors and hematopoietic cell lines. Blood 74, 1235-1240.

Póvoa TF, Alves AM, Oliveira CA, Nuovo GJ, Chagas VL, Paes MV (2014): The pathology of severe dengue in multiple organs of human fatal cases: histopathology, ultrastruc- ture and virus replication. PLoS One 9, e83386. https:// doi.org/10.1371/journal.pone.0083386

Promphan W, Sopontammarak S, Pruekprasert P, Kajornwattanakul W, Kongpattanayothin A (2004): Dengue myocarditis. Southeast Asian J. Trop. Med. Public Health 35, 611-613.

Reed LJ, Muench H (1938): A simple method of estimating fifty per cent endpoints. Am. J. Epidemiol. 27, 493-497. https:// doi.org/10.1093/oxfordjournals.aje.a118408

Remmy MM (2014): Dengue fever: theories of immunopathogenesis and challenges for vaccination. Inflamm. Allergy Drug Targets 13, 262-274. https://doi.org/10.2174/1871 $\underline{528113666140828113158}$

Rice CM, Lenches EM, Eddy SR, Shin SJ, Sheets RL, Strauss JH (1985): Nucleotide sequence of yellow fever virus: implications for flavivirus gene expression and evolution. Science 229, 726-733. https://doi.org/10.1126/ $\underline{\text { science. } 4023707}$

Sabin AB (1952): Research on dengue during World War II. Am. J. Trop. Med. Hyg. 1, 30-50. https://doi.org/10.4269/ ajtmh.1952.1.30

Sahaphong S, Riengrojpitak S, Chirachariyavej T, Bhamarapravati N (1980): Electron microscopic study of the vascular endothelial cell in dengue hemorrhagic fever. Southeast Asian J. Trop. Med. Public Health 11, 194-204.

Salgado DM, Elti JM, Mansfield K, Panqueba C, Castro D, Vega MR, Xhaja K, Schmidt D, Martin KJ, Allen PD, Rodriguez JA, Dinsmore JH, López JR, Bosch I (2010): Heart and skeletal muscle are targets of dengue virus infection. Pediatr. Infect. Dis. J. 29, 238-242. https://doi.org/10.1097/ INF.0b013e3181bc3c5b

Satarasinghe RL, Ramesh R, Riyaaz AA, Gunarathne PA, de Silva AP (2007): Hypothyroidism is a predisposing factor for fenofibrate-induced rhabdomyolysis--patient report and literature review. Drug Metabol. Drug Interact. 22, 279-283. https://doi.org/10.1515/DMDI.2007.22.4.279

Shah I (2007): Dengue presenting as viral myocarditis. Dengue Buletim 31, 172-173.

Sheetal S, Jacob EA (2016): Study on the Cardiac Manifestations of Dengue. J. Assoc. Physicians India 64, 30-34.

Shepard DS, Undurraga EA, Halasa YA, Stanaway JD (2016): The global economic burden of dengue: a systematic analysis. Lancet Infect. Dis. 16, 935-941. https://doi.org/10.1016/ S1473-3099(16)00146-8

Veloso HH, Ferreira Júnior JA, de Paiva JMB, Honório JF, Bellei NCJ, de Paola AAV (2003): Acute atrial fibrillation during dengue hemorrhagic fever. Braz. J. Infect. Dis. 7, 418-422. https://doi.org/10.1590/S1413-86702003000600010

Virk HUH, Inayat F, Rahman ZU (2016): Complete Heart Block in Association with Dengue Hemorrhagic Fever. Korean Circ. J. Nov. 46, 866-869. https://doi.org/10.4070/ kcj.2016.46.6.866

Warke RV, Xhaja K, Martin KJ, Fournier MF, Shaw SK, Brizuela N, Bosch N, Lapointe D, Ennis FA, Rothman AL, Bosch I (2003): Dengue Virus Induces Novel Changes in Gene Expression of Human Umbilical Vein Endothelial Cells. J. Virol. 77, 11822-11832. https://doi.org/10.1128/ IVI.77.21.11822-11832.2003 
Weerakoon KG, Kularatne SA, Edussuriya DH, Kodikara SK, Gunatilake LP, Pinto VG, Seneviratne AB, Gunasena S (2011): Histopathological diagnosis of myocarditis in a dengue outbreak in Sri Lanka, 2009. BMC Res. Notes 4, 268. https://doi.org/10.1186/1756-0500-4-268

World Health Organization. Available online: http://www.who.int/ denguecontrol/disease/en/ (accessed in 01/06/18).

World health organization (2009): Dengue: Guidelines for Diagnosis, Treatment, Prevention and Control. 1st ed. WHO Press, Geneva, Switzerland, pp. 10-12, ISBN: 978-92-4154787-1.
Yu HS, Wang MT, Tai CL, Yang SA, Chien CH (1989): Skin eruption and histopathological changes in dengue fever. Kaohsiung J. Med. Sci. 5, 17-23.

Zellweger RM, Prestwood TR, Shresta S (2010): Enhanced infection of liver sinusoidal endothelial cells in a mouse model of antibody-induced severe Dengue disease. Cell Host Microbe 7, 128-139. https://doi.org/10.1016/j. chom.2010.01.004 